\title{
Ozonated water electrolytically generated by diamond-coated electrodes controlled phytonematodes in replanted soil
}

\author{
Xorla Kanfra $^{1} \cdot$ Ahmed Elhady $^{1,2} \cdot$ Hendrik Thiem $^{3} \cdot$ Sven Pleger $^{3} \cdot$ Markus Höfer $^{3} \cdot$ Holger Heuer $^{1}$ (I)
}

Received: 22 April 2021 / Accepted: 26 August 2021 / Published online: 8 September 2021

(c) The Author(s) 2021

\begin{abstract}
Phytonematodes cause severe yield losses in horticulture, partly because they are difficult to manage. Compact, energyefficient generators that electrochemically produce ozonated water by utilizing diamond-coated electrodes have become available. In this study, the application of on-site generated ozonated water to inactivate soil nematodes and to mitigate nematode-mediated apple replant disease was tested. Pratylenchus penetrans was highly susceptible to dissolved ozone ( $\mathrm{LC}_{50}$ $\left.0.6 \mathrm{mg} \mathrm{L}^{-1}\right)$. In one greenhouse experiment, treatment of $P$. penetrans in soil with ozonated water $\left(0.27 \mathrm{mg}\right.$ ozone $\mathrm{L}^{-1}$ soil $)$ reduced subsequent invasion of the nematodes into roots by $60 \%$. Growth of apple saplings in soil that was affected by apple replant disease (ARD) was significantly improved following a treatment with 1/10 volume ozonated water compared to the control. In a second greenhouse experiment, one-time drenching of ARD soil with ozonated water was followed by improved growth of apple plants similar to that in autoclaved soil. A second application of ozonated water did not further improve plant growth. The number of active nematodes in replanted soil that moved through a Baermann filter was significantly reduced by all tested concentrations of ozone $\left(0.12-0.75 \mathrm{mg} \mathrm{L}^{-1}\right.$ soil). A fraction of $19-36 \%$ of the nematodes survived and slightly recovered after four weeks. In conclusion, on-site generated ozonated water has potential to mitigate nematode problems in horticulture and to expand management options.
\end{abstract}

Keywords Ozone treatment $\cdot$ Apple replant disease $\cdot$ Nematode $\cdot$ Pest control $\cdot$ Horticulture $\cdot$ Soil disinfestation

\section{Introduction}

Nematodes are abundant in soils and play an essential role in ecosystem functions and services (Yeates et al. 1993). Some of the nematodes, mainly the endoparasitic phytonematodes (Elling 2013; Jones et al. 2013), are a major limiting biotic factor of productivity (Singh et al. 2015; Stirling 2014). These nematodes migrate through soil in search of a host plant, invade roots and feed on the cytoplasm of cells, thereby damaging the plant. The endoparasitic root-lesion nematode Pratylenchus penetrans has a wide host range. In soybean, it can impede symbiotic nitrogen fixation and

Holger Heuer

holger.heuer@julius-kuehn.de

1 Institute for Epidemiology and Pathogen Diagnostics, Federal Research Centre for Cultivated Plants, Julius KühnInstitute (JKI), Braunschweig, Germany

2 Faculty of Agriculture, Benha University, Benha, Egypt

3 Fraunhofer Institute for Surface Engineering and Thin Films (IST), Braunschweig, Germany plant growth (Elhady et al. 2020). Etiological relations between some nematodes and microbes in soil-borne disease complexes are known (Back et al. 2002; Morris et al. 2016). For example, $P$. penetrans was reported to exacerbate apple replant disease (ARD), in addition to unknown biotic factors (Dullahide et al. 1994; Jaffee et al. 1982; Oostenbrink and Hoestra 1961). ARD is characterized by reduced vegetative growth of apple trees, root damage and yield decline in replanted soil (Winkelmann et al. 2019). Soil disinfestation techniques directed towards nematodes such as heat at $50{ }^{\circ} \mathrm{C}$ (Yim et al. 2015), Tagetes as preplant (Yim et al. 2017), or application of nematicides (Jaffee et al. 1982; Johnson et al. 1982) resulted in improved plant growth. The peculiar role of nematodes in the development of ARD was further demonstrated by inoculation with nematodes or microbes on apple rootstocks, singly or in combination. ARD was induced in the presence of nematodes from replanted soil, while the microbes alone did not induce ARD but enhanced the disease together with the nematodes (Kanfra et al. 2018). Effective management of nematode-mediated diseases is still challenging. 
Application of synthetic nematicides poses health and environmental risks because of animal and human toxicity (Onkendi et al. 2014; Zasada et al. 2010). Crop rotation is of limited efficacy for plant-parasitic nematodes with a wide host range, and it is often not applicable in fruit and nursery production systems. Anaerobic soil disinfection or biofumigation with plants or seed meal of Brassicaceae could ameliorate ARD (Mazzola et al. 2015). However, these methods are limited by high time requirements, costs, logistical challenges, and the environmentally undesirable use of plastic. Nematode-related problems are further aggravated by the lack of resistant varieties or non-host crops (Cook and Starr 2006). Biological control options may be costly and of unpredictable efficacy (Agbenin 2012; Fourie et al. 2014). Hence, there is a need to exploit alternative mitigation strategies to protect food crops against nematode pests.

Ozone is a versatile and powerful disinfectant (Gray 2014). Dissolved ozone inactivates a wide range of microorganisms, insects, and nematodes (Al-Ahmadi et al. 2009; Perry and Yousef 2011; Qiu et al. 2009). The antimicrobial activity of ozone is attributed to its high oxidation potential. In addition, hydroxyl radicals arise from ozone in water and can break down cell walls and membranes. Ozone is generally regarded as safe because it has a unique property of auto-decomposition and leaves no toxic residues (Carletti et al. 2013). In contrast to gaseous ozone, dissolved ozone decomposes faster and does not pose a toxic risk to respiratory tracts (Kim et al. 2002) or plants (Fujiwara and Fujii 2002). Therefore, recent interest developed in using ozonated water for control of plant diseases (Fujiwara and Fujii 2002; Guo et al. 2019; Zheng et al. 2020).

Application of ozonated water to reduce plant-parasitic nematodes in soil was not comprehensively studied. This may be because ozone is expected to be inefficient in soil. It is assumed that a significant part of its oxidizing power is expended by the reaction with soil organic matter. Production of ozonated water had been highly inefficient until boron-doped diamond electrodes were developed for the continuous electrochemical generation of dissolved ozone directly from water (Arihara et al. 2007; Cobb et al. 2018). These electrodes became commercially available at various scales. As they are robust, energy-efficient and suitable for mobile devices, applications in agriculture and horticulture are becoming possible.

In this study, the hypothesis was tested whether ozonated water reduces nematode populations in soil and improves plant growth. This was tested by exposing $P$. penetrans to various concentrations of dissolved ozone. Concentrationdependent and frequency of application effects of ozonated water on inactivation of nematodes in ARD soil and mitigation of the disease were examined.

\section{Materials and method}

\section{Electrochemical reactor systems for preparation of ozonated water}

Ozonated water was generated using an electrochemical ozone generator (Condiapure ${ }^{\mathrm{TM}}$, Condias $\mathrm{GmbH}$, Itzehoe, Germany) based on electrodes coated with boron-doped diamond that operate efficiently at low voltages. Ozone generation was controlled by operating the electrodes at a constant current (1.0-4.0 A) and 8-15 V. The concentration of dissolved ozone was monitored with a portable photometer (CHEMATEST 30, SWAN Analytische Instrumente, Hinwil, Switzerland) utilizing the DPD method (colorimetric method using $N, N$-dialkyl-1,4-phenylenediamine, ISO 73932:2017).

After applying the electrical current to the diamond electrodes, the ozone concentration increases within about $30 \mathrm{~min}$ to an asymptotic saturation value of $5 \mathrm{mg} \mathrm{L}^{-1}$.

\section{Effect of ozonated water on $P$. penetrans and cuticle-attached bacteria}

The susceptibility of $P$. penetrans to various concentrations of ozone was tested. Mixed infective stages of $P$. penetrans nematodes were extracted and purified from a two-month culture on carrot discs using a Baermann funnel. The extracted nematodes were washed with $20 \mathrm{~mL}$ sterile tap water on a 5- $\mu \mathrm{m}$ sieve (Cell-Trics1 filters, Sysmex, Norderstedt, Germany) and collected in sterile tap water. Ozone was electrochemically generated from ice-cold demineralized water. At various time points during ozone generation over 12 min (electrode on) or the subsequent decay of the generated ozone over $88 \mathrm{~min}$ (electrode off), the ozone concentration was determined and $100 \mu \mathrm{L}$ or $400 \mu \mathrm{L}$ ozonated water were added to microtubes containing 500 nematodes to reach a final volume of $500 \mu \mathrm{L}$. Nematodes in demineralized water served as control. Thereby, the nematodes were exposed to ozonated water at 48 ozone concentrations between 0.03 and $4.2 \mathrm{mg} \mathrm{L}^{-1}$. Four hours after treatment, dead and live nematodes were quantified microscopically based on their body shape (non-mobile straight- to c-shaped animals were recorded as dead nematodes, while mobile worm-shaped animals were recorded as live nematodes). To determine the number of nematode-attached bacteria that survived the ozone treatment, a volume of $100 \mu \mathrm{L}$ of the nematode suspension was plated on R2A media supplemented with $10 \mathrm{mg} \mathrm{L}^{-1}$ cycloheximide. R2A allows for growth of a large variety of bacterial species (Massa et al. 1998). The R2A plates were kept at $28{ }^{\circ} \mathrm{C}$ for two days before counting the colony forming units. 


\section{Effect of ozonated water on the invasion of $P$. penetrans into soybean roots}

In our second experiment, we investigated to what extent ozonated water affected the invasion of $P$. penetrans into soybean roots. Mixed infective stages of $P$. penetrans were prepared as described. Twenty pots were filled with $150 \mathrm{~mL}$ sand $(<1 \mathrm{~mm})$ and inoculated with $10 \mathrm{~mL}$ water containing 2000 mixed stages of $P$. penetrans. Half of the pots were treated with $10 \mathrm{~mL}$ freshly produced ozonated water with $4 \pm 0.4 \mathrm{mg} \mathrm{O}_{3} \mathrm{~L}^{-1}$ and the other pots with $10 \mathrm{~mL}$ of the untreated demineralized water as control. Pots were planted with 10 days old soybean seedlings and kept in the greenhouse at $24{ }^{\circ} \mathrm{C}$ and $16 \mathrm{~h}$ photoperiod. All pots were watered as needed every 2-3 days. Plants were sampled for plant growth evaluation and counting of nematodes in the roots ten days after transplanting. The whole root systems were washed and stained with 1\% acid fuchsin (Bybd et al. 1983) to count the numbers of nematodes inside the roots using a SZX12 stereomicroscope at $40 \times-80 \times$ magnification (Olympus, Hamburg, Germany).

\section{Effect of ozonated water on nematodes in ARD soil}

In the third experiment, we evaluated the effect of ozonated water on total nematode populations in soil, comprising plant-parasitic and free-living species. The soil was sampled from a frequently replanted orchard in the Pinneberg area $\left(53^{\circ} 41^{\prime} 57.1^{\prime \prime} \mathrm{N} 9^{\circ} 40^{\prime} 59.4^{\prime \prime} \mathrm{E}\right)$ and had a high potential to induce nematode-mediated ARD (Mahnkopp et al. 2018). Since 2009, rootstocks of the cultivar 'Bittenfelder Sämling' were planted repeatedly in a two years cycle. The site had four plots randomly arranged with plants showing severe ARD symptoms. From each ARD plot, the soil was sampled around the roots of three individual plants at a depth of $0-30 \mathrm{~cm}$ and sieved through a $5 \mathrm{~mm}$ mesh to homogenize soil. This resulted in 12 replicate samples of ARD soil. Ozonated water with a concentration of $5 \pm 0.5 \mathrm{mg} \mathrm{O}_{3} \mathrm{~L}^{-1}$ was prepared, and $30 \mathrm{ml}$ were applied to $200 \mathrm{ml}$ of ARD soil. Controls received $30 \mathrm{~mL}$ of demineralized water. After incubation overnight, a subsample of $100 \mathrm{~mL}$ soil was placed on a Baermann funnel filled with water to about $5 \mathrm{~mm}$ above the mesh. Nematodes that actively moved through the filter were collected over seven days. The soil was stored after ozone treatment at $4{ }^{\circ} \mathrm{C}$ to test after four weeks whether nematode populations start to recover. The low temperature was chosen to avoid microbial growth which may affect the nematodes. Active nematodes including all trophic groups were extracted by the Baermann technique and counted under a SZX12 stereomicroscope at $40 \times-80 \times$ magnification (Olympus, Hamburg, Germany).
In the fourth experiment, we tested the response of nematodes in ARD soil to varying concentrations of ozonated water. Ozonated water was freshly prepared to drench $200 \mathrm{~mL}$ soil portions in plastic bags with $30 \mathrm{~mL}$ containing $24,48,72,96$, or $120 \mu \mathrm{g} \mathrm{O}_{3}$ corresponding to 0.12 , $0.24,0.36,0.48$, or $0.60 \mathrm{mg} \mathrm{L}^{-1}$ soil, respectively. Controls received $30 \mathrm{~mL}$ of demineralized water. Soil from four replicate ARD plots was used for each treatment. After incubation overnight, subsamples of $100 \mathrm{~mL}$ soil were placed on a Baermann funnel filled with water to about $5 \mathrm{~mm}$ above the mesh, and nematodes actively moving through the filter were collected over seven days and microscopically counted. The remaining $100 \mathrm{~mL}$ soil samples were further incubated for four weeks at $4{ }^{\circ} \mathrm{C}$ before placing it on Baermann funnels to quantify the active nematodes.

\section{Effect of ozonated water on mitigating apple replant disease}

ARD soil was treated once or twice with ozonated water to test whether nematode-mediated growth suppression of apples plants could be alleviated. Portions of $300 \mathrm{~mL}$ ARD soil were drenched with $30 \mathrm{~mL}$ of $5 \pm 0.5 \mathrm{mg} \mathrm{O}_{3} \mathrm{~L}^{-1}$, or $30 \mathrm{~mL}$ demineralized water as control. Half of the soil samples received a second treatment with ozonated water. The soil was transferred to pots and planted with apple rootstocks (M26, Malling 26) that have been propagated in in vitro culture, acclimatized, and grown to $5 \mathrm{~cm}$ shoot length. Pots were placed in randomized complete block design in a greenhouse and watered every $2-3$ days, as required. Fertilizers NPK $(+\mathrm{Mg})[15: 10: 15(+2)]\left(0.5 \mathrm{~g} \mathrm{~L}^{-1}\right)$ and $36 \%$ calcium $\left(2 \mathrm{~g} \mathrm{~L}^{-1}\right)$ were applied weekly. The greenhouse conditions were $22 \pm 2.5^{\circ} \mathrm{C}, 60 \% \pm 8.7 \%$ relative humidity, and a $16 \mathrm{~h}$ photoperiod. Shoot length, shoot fresh mass, number of leafs, leaf fresh mass, and root fresh mass were determined nine weeks after planting. Overall, this experiment comprised 20 replicates for the $1 \times$ ozonated water treatment, 14 replicates for the $2 \times$ ozonated water treatment, and 17 replicates for the water control (some of the plants did not survive transplanting, so that numbers of replicates differed between treatments).

In the sixth experiment, we compared the effect of soil treatment by ozonated water and autoclaving on ARD symptoms of apple plants. For this purpose, portions of $300 \mathrm{~mL}$ ARD soil were filled into bags and disinfected with $30 \mathrm{~mL}$ $5 \pm 0.5 \mathrm{mg} \mathrm{O}_{3} \mathrm{~L}^{-1}$ dissolved ozone or sterilized by autoclaving ( $20 \mathrm{~min}$ at $134{ }^{\circ} \mathrm{C}, 3$ pulses to remove entrapped air). Water treated ARD soil served as control. The treated ARD soil was immediately planted with M26 apple rootstocks and grown as described above. Pots were sampled ten weeks after transplanting to determine shoot length, shoot fresh mass, number of leafs, leaf fresh mass, and root fresh mass. Overall, this experiment comprised 19 replicate pots each 
for ozone and heat treatment, and 20 replicate pots for the untreated control.

\section{Statistical analysis}

Statistical analyses were done using the software package SAS 9.4 (SAS Institute Inc., Cary, NC, United States of America). $\mathrm{LC}_{50}$ concentrations and $95 \%$ fiducial limits were determined using the procedure PROBIT on $\log _{10}$ (dose). The data significantly fitted the probit-log(dose) regression $(P<0.0001)$. The procedure GLIMMIX was used for analyses of variance by fitting data to generalized linear models (GLM). For count data as number of nematodes, colony forming units, or leafs, a Poisson distribution with a log link function was applied. Plant weights and shoot height were analysed with the assumption of a normal distribution without data transformation. For multiple comparisons, the $P$ value was adjusted by the method of Tukey (ADJUST $=$ TUKEY in the LSMEANS statement). To account for overdispersion of the data, degrees of freedom were approximated by the method of Kenward-Roger (DDFM $=$ KENWARDROGER). An effect was regarded as significant at the type I error $P \leq 0.05$.

\section{Results}

\section{Effect of ozonated water on $P$. penetrans and cuticle-attached bacteria}

Exposed to increasing initial ozone concentrations, the percentage of live P. penetrans in suspension decreased (Fig. 1). Probit analysis revealed a $\mathrm{LC}_{50}$ of $0.61 \mathrm{mg} \mathrm{L}^{-1}$ ozone $(95 \%$ fiducial limits: $0.602-0.624 \mathrm{mg} \mathrm{L}^{-1}$ ). More than $99 \%$ of the nematodes were killed at ozone concentrations above $2 \mathrm{mg}$ $\mathrm{L}^{-1}$. The number of bacteria that was naturally attached to the cuticle of the nematodes was determined as plate counts on agar media. The bacteria were even more affected by increasing concentrations of ozone in the suspension than the nematodes (Fig. 1). Probit analysis revealed a $\mathrm{LC}_{50}$ of $0.27 \mathrm{mg} \mathrm{L}^{-1}$ ozone (95\% fiducial limits: $0.258-0.272 \mathrm{mg}$ $\left.\mathrm{L}^{-1}\right)$. This suggested a significantly higher susceptibility of bacteria compared to nematodes, as expected due to direct exposure of bacterial cells in contrast to nematodes that are protected by a cuticle.

\section{Effect of ozonated water on the invasion of $P$. penetrans into soybean roots}

Pratylenchus penetrans was highly susceptible to ozone in water. However, in soil the exposure of nematodes to ozone may be reduced. We treated $150 \mathrm{~mL}$ soil in pots containing $2000 P$. penetrans with $10 \mathrm{~mL}$ ozonated water.

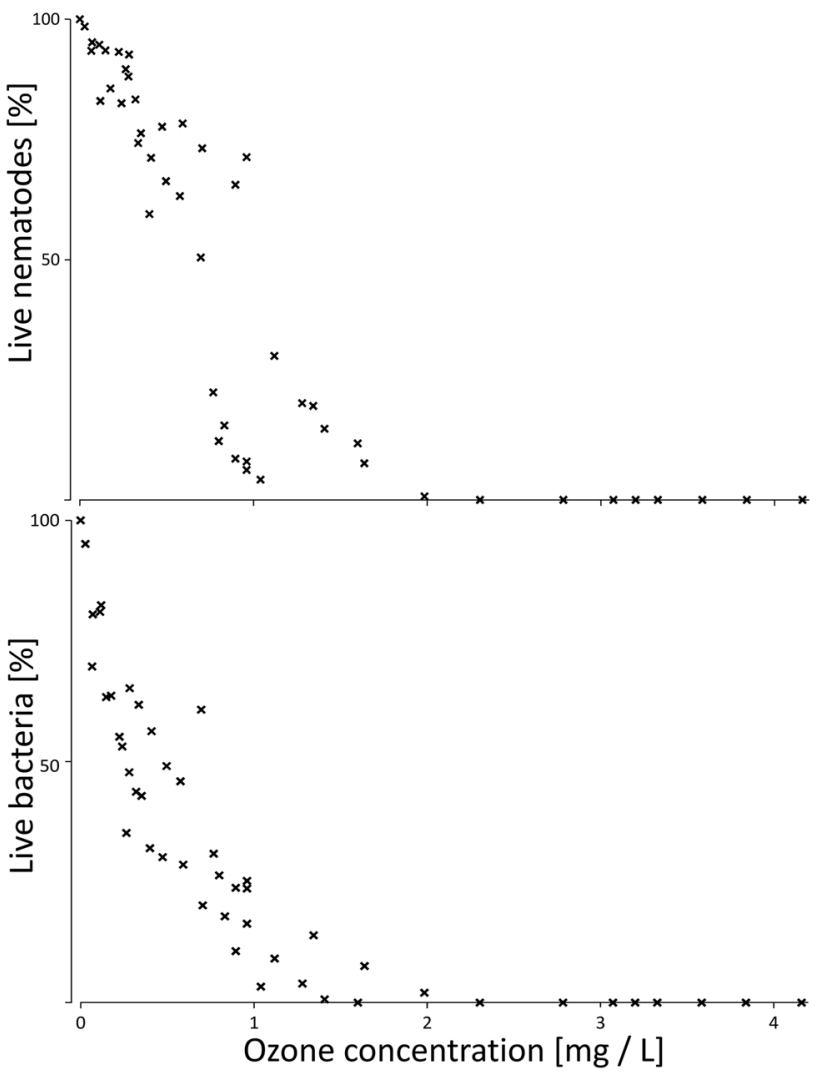

Fig. 1 Lethal doses relation of ozone towards Pratylenchus penetrans and its cuticle-attached bacteria in ozonated water suspension

Soybean seedlings that were planted a day after soil treatment showed significantly less nematodes that penetrated the root (Table 1). Consequently, shoot length and root weight revealed a significantly increased plant growth in ozone treated pots compared to controls (Table 1). Shoot weight showed the same trend, but the difference was not statistically significant.

\section{Effect of ozonated water on nematodes in ARD soil}

The effect of ozonated water on total nematode populations in soil, comprising plant-parasitic and free-living species was evaluated. Drenching of $200 \mathrm{~mL}$ soil with $30 \mathrm{~mL}$ ozonated water corresponding to $0.75 \mathrm{mg} \mathrm{O}_{3} \mathrm{~L}^{-1}$ soil significantly reduced the number of nematodes that actively moved through the filter on a Baermann funnel compared to the control (Fig. 2). The effect was consistent four weeks after treatment despite the increased instability of ozone in soil. The average reduction in active nematodes was $81 \%$ a week after treatment and decreased to $71 \%$ four weeks after treatment. This suggested that only few nematodes recovered from exposure to ozone within four weeks.

Different concentrations of ozone starting from $0.024 \mathrm{mg}$ $\mathrm{L}^{-1}$ soil reduced the number of active nematodes in ARD 
Table 1 Effect of ozone treatment of soil containing 2000 Pratylenchus penetrans on subsequent root invasion of nematodes and growth of soybean plants (mean $\pm \mathrm{SE}$, $n=10$ )

\begin{tabular}{lllll}
\hline Treatment & Plant height $(\mathrm{cm})$ & Root weight $(\mathrm{g})$ & Shoot weight $(\mathrm{g})$ & $\begin{array}{l}\text { Nematodes } \\
\text { per root } \\
\text { system }\end{array}$ \\
\hline Ozonated water $(n=10)$ & $32.7 \pm 2.1$ & $2.3 \pm 0.1$ & $1.7 \pm 0.2$ & $319 \pm 33$ \\
Untreated water $(n=9)$ & $26.0 \pm 2.2$ & $1.3 \pm 0.1$ & $1.4 \pm 0.1$ & $791 \pm 41$ \\
GLM & $P=0.039$ & $P=0.0001$ & $P=0.10$ & $P=0.0001$ \\
\hline
\end{tabular}

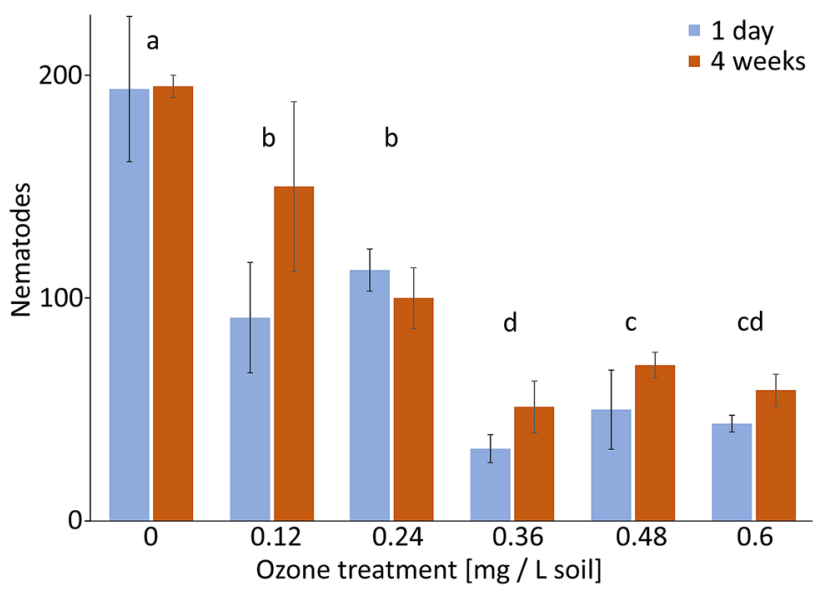

Fig. 3 Number of active nematodes in apple replant diseased soil, one day or four weeks after soil treatment with different concentrations of ozonated water, or untreated water. Different letters indicate significant differences among treatments by different amounts of ozone (GLM with treatment as factor and time as confounding factor, Tukey's adjustment, $P \leq 0.05)$. Error bars indicate SE $(n=4)$

\section{Effect of Ozonated water on mitigating apple replant disease}

We tested whether the treatment of ARD soil with ozonated water improved growth of apple plants. Apple plants grown in treated soil did not show disease symptoms compared to the plants grown in untreated ARD soil. The plants showed significantly increased shoot length, shoot weight, root weight, leaf counts, and leaf weight compared to the plants grown in control soil, which showed the typical growth depression associated with apple replant disease (Table 2). The effect of the number of ozone treatments, however, was negligible, indicating that a single application substantially affects the species involved in the disease complex.

We compared the efficacy of soil treatment by ozonated water to soil sterilization by autoclaving at $134{ }^{\circ} \mathrm{C}$ in alleviating apple replant disease symptoms of plants grown in these soils. Apple plants that were grown in soil treated with ozonated water or sterilized by heat had no disease symptoms after nine weeks when compared to plants grown in untreated soil (Table 3). Plant growth was similar in ozonated water and heat-treated soils and significantly better than in untreated soil. Root weight in ozone treated soil was 
Table 2 Effect of ozonated water applied one or two times to apple replant disease soil on growth of apple plantlets

\begin{tabular}{llllll}
\hline $\begin{array}{l}\text { Soil treatment before plant- } \\
\text { ing (replicate pots) }\end{array}$ & Shoot length $(\mathrm{cm})^{*}$ & Shoot fresh mass $(\mathrm{g})$ & Root fresh mass $(\mathrm{g})$ & Leaf count & Leaf fresh mass $(\mathrm{g})$ \\
\hline $2 \times$ Ozonated water $(14)$ & $8.2 \pm 1.4 \mathrm{a}$ & $2.3 \pm 0.4 \mathrm{a}$ & $1.3 \pm 0.4 \mathrm{a}$ & $14.2 \pm 1.9 \mathrm{a}$ & $1.4 \pm 0.3 \mathrm{a}$ \\
$1 \times$ Ozonated water $(20)$ & $8.1 \pm 1.4 \mathrm{a}$ & $2.4 \pm 0.5 \mathrm{a}$ & $1.2 \pm 0.4 \mathrm{a}$ & $14.2 \pm 2.8 \mathrm{a}$ & $1.5 \pm 0.4 \mathrm{a}$ \\
Untreated water $(17)$ & $6.5 \pm 0.9 \mathrm{~b}$ & $1.3 \pm 0.4 \mathrm{~b}$ & $0.5 \pm 0.2 \mathrm{~b}$ & $10.6 \pm 1.8 \mathrm{~b}$ & $0.9 \pm 0.3 \mathrm{~b}$ \\
\hline
\end{tabular}

$*$ Mean $\pm \mathrm{SD}$, different letters indicate significant differences (GLM with Tukey's adjustment, $P \leq 0.05$ )

Table 3 Effect of ozonated water in comparison to soil autoclaving on growth of apple plantlets in soil with apple replant disease

\begin{tabular}{llllll}
\hline $\begin{array}{l}\text { Soil treatment before plant- } \\
\text { ing (replicate pots) }\end{array}$ & Shoot length $(\mathrm{cm})^{*}$ & Shoot fresh mass $(\mathrm{g})$ & Root fresh mass $(\mathrm{g})$ & Leaf count & Leaf fresh mass $(\mathrm{g})$ \\
\hline Ozonated water $(19)$ & $13.0 \pm 1.9 \mathrm{a}$ & $3.5 \pm 1.2 \mathrm{a}$ & $4.1 \pm 1.4 \mathrm{a}$ & $16.0 \pm 4.9 \mathrm{a}$ & $2.0 \pm 0.6 \mathrm{a}$ \\
Autoclaving $134^{\circ} \mathrm{C}(19)$ & $13.6 \pm 2.1 \mathrm{a}$ & $4.5 \pm 0.8 \mathrm{~b}$ & $4.8 \pm 1.6 \mathrm{a}$ & $18.3 \pm 3.1 \mathrm{a}$ & $2.7 \pm 0.5 \mathrm{~b}$ \\
Untreated water (20) & $10.5 \pm 1.2 \mathrm{~b}$ & $2.6 \pm 0.7 \mathrm{c}$ & $1.6 \pm 0.5 \mathrm{~b}$ & $10.3 \pm 2.0 \mathrm{~b}$ & $1.5 \pm 0.5 \mathrm{c}$ \\
\hline
\end{tabular}

$*$ Mean $\pm \mathrm{SD}$, different letters indicate significant differences (Tukey’s test, $P \leq 0.05$ )

2.6 times higher in comparison to the untreated control. The latter showed a typical brownish discolouration. Shoot and leaf weight of apple plants grown in heat-treated soil were significantly larger compared to plants grown in soil treated by ozonated water, and this trend was also observed for shoot length, root weight, and leaf number (Table 3).

\section{Discussion}

In this study, we tested whether application of ozonated water to control nematode pests could become a promising strategy. In suspension, mixed infective stages of the plantparasitic nematode $P$. penetrans were highly susceptible to dissolved ozone, with $50 \%$ mortality at $0.6 \mathrm{mg}$ ozone $\mathrm{L}^{-1}$. For juveniles of the root-knot nematode Meloidogyne incognita, a mortality of $91 \%$ was reported when treated twice with $0.5 \mathrm{mg} \mathrm{L}^{-1}$ ozone dissolved in a nutrient solution for soilless cultivation of plants (Zheng et al. 2020). Eggs of Meloidogyne enterolobii were inactivated when suspended in $0.55 \mathrm{mg} \mathrm{L}^{-1}$ ozone for $15 \mathrm{~min}$ (Landa Fernández et al. 2019). Ozone concentrations per litre soil are not directly comparable to concentrations in water, because only a minor part of the soil volume is water. Ozonated water films are unevenly distributed in soil and target organisms can be protected in cavities. Disinfection efficiency of dissolved ozone is expected to be much lower in soil than in solution, because decomposition of ozone is accelerated by oxidation of soil organic matter. In our greenhouse experiment, application of $0.27 \mathrm{mg}$ dissolved ozone per litre of sand significantly affected $P$. penetrans, so that its invasion into roots of subsequently grown plants was reduced by $60 \%$, and plant growth was significantly increased compared to controls.
Similarly, dissolved ozone was effective in growth substrate in the study of Zheng et al. (2020). Three times application of $200 \mathrm{ml}$ of a nutrient solution containing $4 \mathrm{mg} \mathrm{L}^{-1}$ ozone to eight litre of a peat-vermiculite-perlite substrate reduced juveniles of $M$. incognita by $88 \%$ and significantly affected egg hatching. Saeedizadeh et al. (2019) tested the response of Meloidogyne javanica to ozonated water in petri dishes or in the root zone of tomato seedlings grown in pots. They reported that in both systems, ozone was efficient in controlling the nematode eggs and the second stage juveniles, leading to reduced root galling. In another study, five-month-old potato plants with a heavy infestation of root-knot nematodes were irrigated with ozonated water or non-ozonated water (Behzadi et al. 2012). After 20 days of irrigation, plants that received ozonated water developed new root systems that were no longer infected with the nematodes compared to the water irrigated plants.

We investigated whether ozonated water is efficient in treating replanted soil of tree nurseries or apple orchards to mitigate ARD symptoms of apple plants. The disease is characterized by retarded vegetative growth of apple trees and yield decline (Winkelmann et al. 2019). Plantparasitic nematodes, especially $P$. penetrans, have been shown to affect apple plants (Jaffee et al. 1982). In a previous study, we showed that ARD is likely mediated by nematodes other than plant-parasitic nematodes (Kanfra et al. 2018). The definite cause of ARD is still not clear but multitrophic interactions of biological agents have been proposed to cause ARD (Nicola et al. 2018). Hence, designing a sustainable management measure for the disease without the known cause is difficult. In our study, growth of apple plants in replanted soil was significantly improved by a preceding treatment with ozonated water, 
compared to the control. A single dose of ozonated water was nearly as effective as autoclaving of soil, while a second dose of ozonated water after a week did not further improve subsequent plant growth. Heat treatment of ARD soil at $50{ }^{\circ} \mathrm{C}$ or $100{ }^{\circ} \mathrm{C}$ was shown to alleviate the disease symptoms and improve plant growth significantly (Yim et al. 2013, 2015), but steaming of soil requires huge energy and is economically not viable (Winkelmann et al. 2019). Nutrients released from biota that were killed by ozone probably did not contribute to plant growth because the plants received sufficient fertilizer. Root systems in untreated ARD soil were reduced in volume and blackened, and the number of leaves and shoot fresh weight was decreased indicating typical growth depression associated with ARD symptoms (Grunewaldt-Stöcker et al. 2019). We showed previously that microbes attached to the bodies of specific nematodes synergistically enhanced replant disease of apple plants (Kanfra et al. 2018). Therefore, it is interesting to note that the microbes attached to the cuticle of $P$. penetrans were also affected by ozone in the present study. The number of actively moving nematodes in replanted soil was drastically reduced by doses above $0.36 \mathrm{mg}$ ozone per litre of soil, which can be practically achieved. However, a fraction of $19-36 \%$ of the nematodes in soil remained active, significantly recovered within four weeks and recolonized the soil. Resilience of the soil biota after treatment with ozonated water needs further investigation. In this respect, the fast decomposition of ozone without toxic residuals is advantageous for the recovery of the soil biota. This process might be enhanced and controlled by soil amendments with composts or beneficial consortia of microbes to support the antagonistic potential of the soil against pests and pathogens (Sikora and Pocasangre 1992).

The electrochemical generation of ozonated water by means of diamond-coated electrodes has proven to be an intrinsically safe, energy-efficient and environmentally friendly technique with high potential for agricultural applications. For generating $5 \mathrm{mg}$ ozone in $1 \mathrm{~L}$ water, an electrical energy of only $30 \mathrm{Wh}$ was consumed in this study. This excellent energy efficiency in combination with the low system requirements is a big benefit of electrochemical ozone generators based on diamond electrodes. Due to the low operating voltages, diamond-based ozone generators can be directly powered by the 12-24 V on-board voltages commonly available in agricultural vehicles. On-site generation of ozonated water, which is necessary due to the short halflive of ozone, is achieved by compact and scalable devices and can be easily controlled by adjustment of current. It offers the opportunity for replacing harmful pesticides or fumigants by a short-lived oxidant that is generated ondemand from water and cannot be overdosed. The next steps will be to adapt already existing industrial-scale diamond ozone generators to the requirements of agricultural applications and to investigate technical and economic feasibility in outdoor operation.

Acknowledgements We thank A. Wrede for soil samples from his field trial, and T. Winkelmann and E. Schneider for in vitro propagated M26 apple plants.

Authors' contributions Conceptualization, supervision, validation by $\mathrm{HH}$ and MH. Experiments done by XK, AE, HT, and SP. Writing of draft manuscript by $\mathrm{XK}$ and $\mathrm{AE}$. Data analyses by $\mathrm{HH}, \mathrm{XK}$, and $\mathrm{AE}$. Review and editing by $\mathrm{HH}$ and $\mathrm{MH}$.

Funding Open Access funding enabled and organized by Projekt DEAL. XK was funded by the German Federal Ministry of Research and Education Grant 031B0512B, and AE was funded by the German Research Foundation (DFG) Grant EL 1038/2-1.

Availability of data and material (data transparency) Data are available from the corresponding author on reasonable request.

\section{Declarations}

Conflict of interest The authors declare no competing interests.

Open Access This article is licensed under a Creative Commons Attribution 4.0 International License, which permits use, sharing, adaptation, distribution and reproduction in any medium or format, as long as you give appropriate credit to the original author(s) and the source, provide a link to the Creative Commons licence, and indicate if changes were made. The images or other third party material in this article are included in the article's Creative Commons licence, unless indicated otherwise in a credit line to the material. If material is not included in the article's Creative Commons licence and your intended use is not permitted by statutory regulation or exceeds the permitted use, you will need to obtain permission directly from the copyright holder. To view a copy of this licence, visit http://creativecommons.org/licenses/by/4.0/.

\section{References}

Agbenin NO (2012) Biological control of plant parasitic nematodes: prospects and challenges for the poor Africa farmer. Plant Protect Sci 47:62-67. https://doi.org/10.17221/46/2010-PPS

Al-Ahmadi SS, Ibrahim RA, Ouf SA (2009) Application of ozone to control insect pests and moulds of date fruits. Biosci Biotech Res Asia 6:435-446

Arihara K, Terashima C, Fujishima A (2007) Electrochemical production of high-concentration ozone-water using freestanding perforated diamond electrodes. J Electrochem Soc 154:E71-E75. https://doi.org/10.1149/1.2509385

Back MA, Haydock PPJ, Jenkinson P (2002) Disease complexes involving plant parasitic nematodes and soilborne pathogens. Plant Pathol 51:683-697. https://doi.org/10.1046/j.1365-3059.2002. 00785.x

Behzadi HR, Samadi N, Samadi A, Safari M, Shahi S, Qaryan M (2012) The ozone application for control of the root-knot nematode in tomato greenhouse. Elixir Agric 48:9387-9389

Bybd DW, Kirkpatrick T, Barker KR (1983) An improved technique for clearing and staining plant tissues for detection of nematodes. J Nematol 15:142-143 
Carletti L, Botondi R, Moscetti R, Stella E, Monarca D, Cecchini M, Massantini R (2013) Use of ozone in sanitation and storage of fresh fruits and vegetables. J Food Agric Environ 11:585-589

Cobb SJ, Ayres ZJ, Macpherson JV (2018) Boron doped diamond: a designer electrode material for the twenty-first century. Annu Rev Anal Chem 11:463-484. https://doi.org/10.1146/annur ev-anchem-061417-010107

Cook R, Starr JL (2006) Resistant cultivars. In: Perry RN, Moens M (eds) Plant nematology. CABI, Wallingford, pp 370-391

Dullahide SR, Stirling GR, Nikulin A, Stirling AM (1994) The role of nematodes, fungi, bacteria, and abiotic factors in the etiology of apple replant problems in the Granite Belt of Queensland. Aust J Exp Agric 34:1177-1182. https://doi.org/10.1071/EA9941177

Elhady A, Hallmann J, Heuer H (2020) Symbiosis of soybean with nitrogen fixing bacteria affected by root lesion nematodes in a density-dependent manner. Sci Rep. https://doi.org/10.1038/ s41598-020-58546-x

Elling AA (2013) Major emerging problems with minor Meloidogyne species. Phytopathology 103:1092-1102. https://doi.org/10.1094/ PHYTO-01-13-0019-RVW

Fourie H, van Aardt WJ, Venter C, Tiedt LR (2014) The effects of CropGuard $\AA$ on the motility, ultrastructure, and respiration of two Meloidogyne species. Nematropica 44:85-92

Fujiwara K, Fujii T (2002) Effects of spraying ozonated water on the severity of powdery mildew infection on cucumber leaves. Ozone Sci Eng 24:463-469. https://doi.org/10.1080/019195102089016 35

Gray NF (2014) Ozone disinfection. In: Percival SL (ed) Microbiology of waterborne diseases: microbiological aspects and risks, 2nd edn. Academic Press, London, pp 599-615

Grunewaldt-Stöcker G, Mahnkopp F, Popp C, Maiss E, Winkelmann $\mathrm{T}$ (2019) Diagnosis of apple replant disease (ARD): microscopic evidence of early symptoms in fine roots of different apple rootstock genotypes. Sci Hortic 243:583-594. https://doi.org/10. 1016/j.scienta.2018.09.014

Guo Z, Wang Z, Li Y, Wang Q (2019) Effect of different concentrations of ozone on in vitro plant pathogens development, tomato yield and quality, photosynthetic activity and enzymatic activities. Ozone Sci Eng 41:531-540. https://doi.org/10.1080/01919512. 2019.1591268

Jaffee BA, Abawi GS, Mai WF (1982) Role of soil microflora and Pratylenchus penetrans in an apple replant disease. Phytopathology 72:247-251

Johnson PW, Dirks VA, Pree DJ, Marks CF (1982) Systemic nematicides for control of Pratylenchus penetrans during apple orchard establishment in Ontario. Plant Dis 66:299-301

Jones JT, Haegeman A, Danchin EGJ, Gaur HS, Helder J, Jones MGK, Kikuchi T, Manzanilla-López R, Palomares-Rius JE, Wesemael WML (2013) Top 10 plant-parasitic nematodes in molecular plant pathology. Mol Plant Pathol 14:946-961. https://doi.org/10.1111/ mpp.12057

Kanfra X, Liu B, Beerhues L, Sørensen SJ, Heuer H (2018) Free-living nematodes together with associated microbes play an essential role in apple replant disease. Front Plant Sci 9:1666. https://doi. org/10.3389/fpls.2018.01666

Kim J-G, Yousef AE, Khadre MA (2002) Ozone and its current and future application in the food industry. In: Taylor S (ed) Advances in food and nutrition research, vol 45, 1st edn. Elsevier Textbooks, Amsterdam., pp 167-218

Landa Fernández IA, Monje-Ramirez I, Ledesma O, de Velásquez MT (2019) Tomato crop improvement using ozone disinfection of irrigation water. Ozone Sci Eng 41:398-403. https://doi.org/10.1080/ 01919512.2018.1549474

Mahnkopp F, Simon M, Lehndorff E, Pätzold S, Wrede A, Winkelmann $\mathrm{T}$ (2018) Induction and diagnosis of apple replant disease (ARD): a matter of heterogeneous soil properties? Sci Hortic 241:167177. https://doi.org/10.1016/j.scienta.2018.06.076

Massa S, Caruso M, Trovatelli F, Tosques M (1998) Comparison of plate count agar and R2A medium for enumeration of heterotrophic bacteria in natural mineral water. World J Microbiol Biotechnol 14

Mazzola M, Hewavitharana SS, Strauss SL (2015) Brassica seed meal soil amendments transform the rhizosphere microbiome and improve apple production through resistance to pathogen reinfestation. Phytopathology 105:460-469. https://doi.org/10.1094/ PHYTO-09-14-0247-R

Morris KA, Langston DB, Dutta B, Davis RF, Timper P, Noe JP, Dickson DW (2016) Evidence for a disease complex between Pythium aphanidermatum and root-knot nematodes in cucumber. Plant Health Progr 17:200-201. https://doi.org/10.1094/ PHP-BR-16-0036

Nicola L, Insam H, Pertot I, Stres B (2018) Reanalysis of microbiomes in soils affected by apple replant disease (ARD): old foes and novel suspects lead to the proposal of extended model of disease development. Appl Soil Ecol 129:24-33. https://doi.org/10.1016/j. apsoil.2018.04.010

Onkendi EM, Kariuki GM, Marais M, Moleleki LN (2014) The threat of root-knot nematodes (Meloidogyne spp.) in Africa: a review. Plant Pathol 63:727-737. https://doi.org/10.1111/ppa.12202

Oostenbrink M, Hoestra H (1961) Nematode damage and "specific sickness" in Rosa, Malus and Laburnum. T Pl-Ziekten 67:264-272

Perry JJ, Yousef AE (2011) Decontamination of raw foods using ozone-based sanitization techniques. Annu Rev Food Sci Technol 2:281-298. https://doi.org/10.1146/annurev-food-022510-133637

Qiu JJ, Westerdahl BB, Pryor A (2009) Reduction of root-knot nematode, Meloidogyne javanica, and ozone mass transfer in soil treated with ozone. J Nematol 41:241-246

Saeedizadeh A, Niasti F, Ameri-Bafghi ME, Agahi K (2019) Response of root-knot nematode Meloidogyne javanica to ozone. Ciênc Agrotec. https://doi.org/10.1590/1413-7054201943008419

Sikora RA, Pocasangre L (1992) Management of the antagonistic potential in agricultural ecosystems for the biological control of plant parasitic nematodes. Annu Rev Phytopathol 30:245-270. https://doi.org/10.1146/annurev.py.30.090192.001333

Singh S, Singh B, Singh AP (2015) Nematodes: a threat to sustainability of agriculture. Procedia Environ Sci 29:215-216. https:// doi.org/10.1016/j.proenv.2015.07.270

Stirling GR (2014) Biological control of plant parasitic nematodes, 2nd edn. Soil ecosystem management in sustainable agriculture. CABI, Wallingford, UK

Winkelmann T, Smalla K, Amelung W, Baab G, Grunewaldt-Stöcker G, Kanfra X, Meyhöfer R, Reim S, Schmitz M, Vetterlein D, Wrede A, Zühlke S, Grunewaldt J, Weiß S, Schloter M (2019) Apple replant disease: causes and mitigation strategies. Curr Issues Mol Biol 30:89-106. https://doi.org/10.21775/cimb.030. 089

Yeates GW, Bongers T, de Goede RGM, Freckman DW, Georgieva SS (1993) Feeding habits in soil nematode families and genera - an outline for soil ecologists. J Nematol 25:315-331

Yim B, Smalla K, Winkelmann T (2013) Evaluation of apple replant problems based on different soil disinfection treatments-links to soil microbial community structure? Plant Soil 366:617-631. https://doi.org/10.1007/s11104-012-1454-6

Yim B, Winkelmann T, Ding G-C, Smalla K (2015) Different bacterial communities in heat and gamma irradiation treated replant disease soils revealed by $16 \mathrm{~S}$ rRNA gene analysis-contribution to improved aboveground apple plant growth? Front Microbiol 6:1224. https://doi.org/10.3389/fmicb.2015.01224

Yim B, Nitt H, Wrede A, Jacquiod S, Sørensen SJ, Winkelmann T, Smalla K (2017) Effects of soil pre-treatment with Basamid ${ }^{\circledR}$ granules, Brassica juncea, Raphanus sativus, and Tagetes patula 
on bacterial and fungal communities at two apple replant disease sites. Front Microbiol 8:1604. https://doi.org/10.3389/fmicb.2017. 01604

Zasada IA, Halbrendt JM, Kokalis-Burelle N, LaMondia J, McKenry MV, Noling JW (2010) Managing nematodes without methyl bromide. Annu Rev Phytopathol 48:311-328. https://doi.org/10.1146/ annurev-phyto-073009-114425

Zheng L, Yang Q, Song W (2020) Ozonated nutrient solution treatment as an alternative method for the control of root-knot nematodes in soilless cultivation. Ozone Sci Eng 42:371-376. https://doi.org/ $10.1080 / 01919512.2019 .1695580$

Publisher's Note Springer Nature remains neutral with regard to jurisdictional claims in published maps and institutional affiliations. 